\title{
PREVENTING CLIMATE DISASTERS IN PEAT ECOSYSTEM USING BIO-WASTE MATERIALS FOR CANAL BLOCK MODULES
}

\author{
RM RUSTAMAJI', NURHAYATI', Ivan SUJANA ${ }^{3}$, GuSti HARDIANSYAH ${ }^{4}$, \\ RESDIANSYAH ${ }^{5}$, Wayan SUPARTA ${ }^{6}$ (D)
}

DOI: 10.21163/GT_2020.151.29

\begin{abstract}
:
Peat ecosystems play a very important role in controlling global climate stability. Massive channel development in the peatland ecosystem can have an impact on excessive drying of peatland, which is caused by increased water flow rate and decreased water-saving power in the peat region and implicates the increased oxidation, and the vulnerability of fire hazards which contribute to the disaster of climate change. Recovery of degraded and drained peat can be done by building peat rewetting infrastructure, one of which is canal blocking. This study aims to utilize bio-waste material namely coconut fiber waste (CFW) for composite panels for canal block modules. This research was carried out using the hand lay-up method, with composite compositions in the form of polyester, fiberglass, wire mesh, and coconut fiber. The results showed that the composition of the type $\mathrm{C}$ composite panel samples had a density value of $0.0853 \mathrm{gr} / \mathrm{cm}^{3}$, the moisture content value was only $0.16 \%$, thickness swelling was only $0.11 \%$, and the length swelling was only $0.01 \%$, better than other samples. Besides, the type $\mathrm{C}$ composite panel sample is also better, with a modulus of rupture (MoR) of $21.845 \mathrm{kgf} / \mathrm{mm}^{2}$, modulus of elasticity (MoE) value of $78.057 \mathrm{kgf} / \mathrm{mm}^{2}$, and impact energy 79.66 Joules. It is expected that coconut fiber waste can be processed and used optimally as a bio-waste for canal block in preventing fire hazards (disaster climate change).
\end{abstract}

Key-words: Climate change, Bio-waste, Coconut fiber, Canal block, Peat ecosystem.

\section{INTRODUCTION}

Indonesia is a developing country and is one of the world's emerging economies that has one of the fastest economic growth rates. One of the driving forces of this growth has been the large-scale exploitation of its extensive natural resources, including its peat swamp forests, in recent decades, especially in Borneo Island (Miettinen et al., 2012).

Indonesia ranks eighth of the world's largest forest and has the largest peatland in Southeast Asia. Total forest area covers $50 \%$ of Indonesia land $\left(\sim 940,000 \mathrm{~km}^{2}\right)$ and approximately $12 \%$ of the land is peatland ecosystem $\left(\sim 200,000 \mathrm{~km}^{2}\right)$. A part from that, Kalimantan is the third largest island in the world, which has the second biggest tropical peat swamp forest with a higher amount of carbon storage in Indonesia.

${ }^{123}$ Universitas Tanjung Pura, Faculty of Engineering, 78124, Pontianak City, West Kalimantan, maji.soenantyo@gmail.com,ivan_sujana30@yahoo.com,nuhayatiuntan@gmail.com, gusti.hardiansyah@gmail.com

${ }^{4}$ Universitas Tanjung Pura, Faculty of Forestry, 78124, Pontianak City, West Kalimantan, gustihardiansyah@fahutan.untan.ac.id

${ }^{5}$ Universitas Pembangunan Jaya, Dept of Civil Engineering, Faculty of Technology and Design, 15413, Tangerang Selatan, Indonesia, resdiansyah.mansyur@upj.ac.id.

${ }^{6}$ Universitas Pembangunan Jaya, Dept of Informatics, Faculty of Technology and Design, 15413, Tangerang Selatan,Indonesia, drwaynesparta@gmail.com 
Given that surrounding land-use change affects the function of protected areas, it is crucial to identify the driving forces that influence them and modelling future changes to prevent further decline of natural resources (Rafaai et al., 2020), Based on study in Nigeria, the results showed that the drivers of land use changes in Nigeria were the gross regional product, average temperature, migration and population density, in which the gross regional product and migration had the highest impacts on land use change (Ighile \& Shirakawa, 2020). Awareness of the preservation of natural resources for the next generation has become an international concern, especially highlighting water exploration for the manufacturing sector in the production process (Dwianika et al., 2020). Since 1950s, legal and illegal logging contributed on 30\% of tropical forests loss in Indonesia (Hayasaka, 2012). The change of ecology after forest loss result such uncontrolled forest and peat fire in lasts century. Peatlands provide an important sink of carbon in their near natural state but potentially act as a source of gaseous and dissolved carbon emission if not in good condition (Rebekka et al., 2019). One of the worst eco-disasters on the planet is currently unfolding in Indonesia. Over the past two months in 2015, thousands of forest and peatland fires have been raging out of control, choking the entire region in a thick and toxic haze.

Besides, peat ecosystems play a very important role, both as a supporter of economic activity and as an element of sustainability diverse local life. Besides, the peat ecosystem also serves as controlling global climate stability, which is due to its ability to absorb and store carbon (C), (Ministry of Env., 2012). Scientific studies have shown that the massive channel development in the peatland ecosystem associated with logging activities can have an impact on excessive drying of peatland, which is caused by increased water flow rate and decreased water-saving power in the peat region and implicates the increased oxidation, and the vulnerability of fire hazards. The recovery of peat degraded and drainage can be done by building a peat wetting infrastructure, one of which is through the existing trench/conduit (canal blocking) activities with the block/dam system. So it is expected that high water advance and water retention in peat can be increased, to minimize the occurrence of fire hazards in the dry season and facilitate the rehabilitation of the surrounding areas. In the activity of the channel insulation, the partition material used is influenced by the size of the channel, easily obtained around the location, strong and durable (not easily weathered), not easily damaged (either by water flow, animal or human). But with the many uses of boards/wooden beams as a channel material from the local location, it will be increasingly damaging the environment itself. This study aims to examine the utilization of coconut fiber waste into composite material as a substitute material from the board/wood beam, to be applied as canal blocking. This study resulted in a product of canal block module made from raw coconut waste composite to be applied on a 3-meter wide water channel and 1-metre depth. The results of this study are expected to support government policy in the implementation of peat restoration in Indonesia.

\section{METHODOLOGY}

This research uses survey methods, laboratory testing and field testing with the steps of research implementation as shown in Fig. 1. A more detailed explanation of the research steps as ilustrated in Figure 1 is as follows:

\section{STEP 1: Identification and analysis canal site}

In this initial step, identification and analysis canal site done with a field survey was carried out including measuring cross section, lengthwise, depth of the canal and measuring 
the flow of water flow on the canal to be installed in the canal block construction. As known, peat soil is a land that is formed from the accumulation of organic materials such as remnants of plant tissues that take place in a long period and generally always submerged throughout

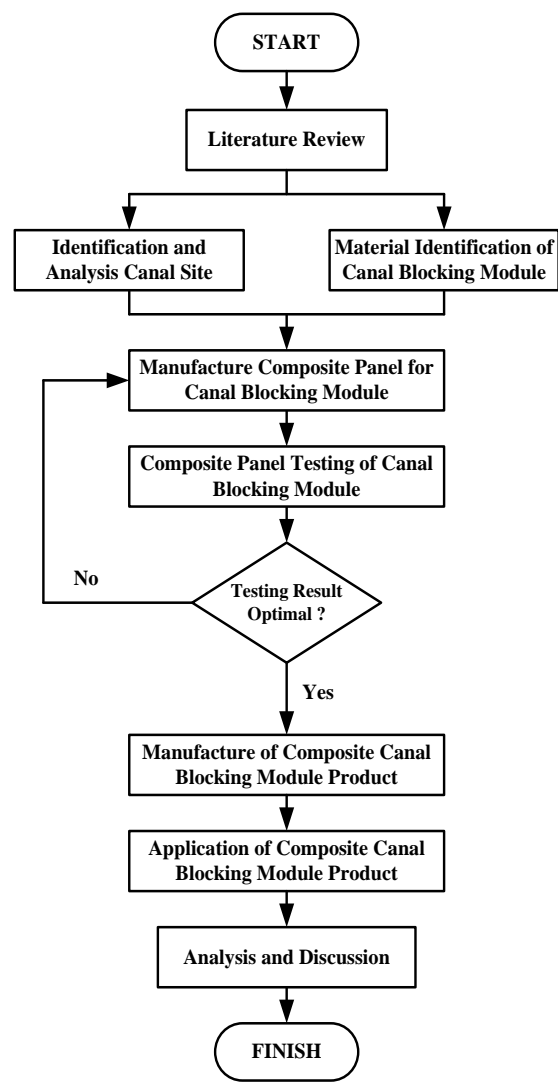

Fig. 1. Flowchart of research. the year. Known as peatland when the thickness of peat is more than $50 \mathrm{~cm}$, (Najiyati et al., 2005). Further, hydrological cycles are the basic concepts of equilibrium and water movement on the Earth, as shown in Fig. 2.

To examine the drought affected area is highly challenging because the drought is a natural disaster that starts and expands slowly. The severity of the drought is different when the rainfall is imbalance in the area (Rotjanakusol \& Laosuwan, 2019). Based on the hydrological cycle, to prevent the reduction of groundwater face as a result of forest immaterial and the presence of trenches and open channels, control is required. One way to control the decline of groundwater in peatland is through canal blocking. It is expected that the groundwater advance in peatland will increase and peat does not suffer from drought.

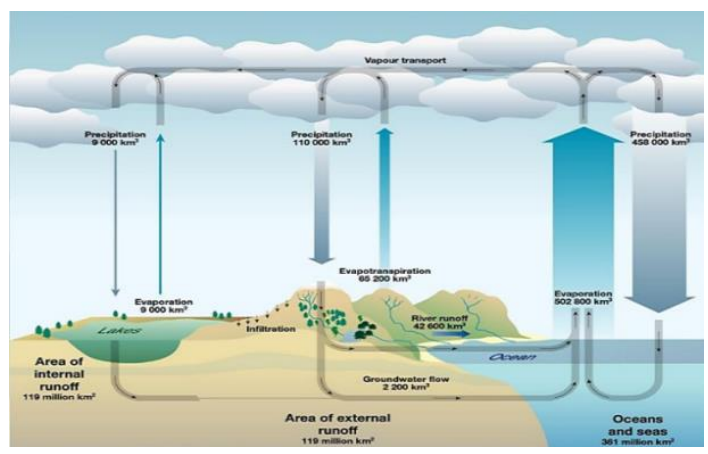

Fig. 2. Hydrological Cycle

(Source: Max Planck Institute for Meteorology, 1999)

\section{STEP 2: Material identification of Canal Blocking Module}

In the next step, the process of identifying the main types of material needed to make the canal block composite module as a substitute for wood which has been used to block the canals. One of potential bio-waste material can be used in canal blocking system is coconut coir. Coconut coir is one of the by-products of the coconut fruit that is in the form of coarse fibers. Coconut coir composes about $35 \%$ of total fruit weight. Coconut Coir has some properties such as durable, resistant to friction and not easily broken, resistant to water (not easy to decay), resistant to fungi and pests. Excess of coconut fiber is, 1) anti-moths, resistant to fungi, 2) provide excellent insulation against temperature and sound, 3) non-flammable, 4) flame-retardant, 5) unaffected by moisture and humidity, 6) durable, and 7) static (Satyanarayana et al.,1982). 


\section{STEP 3: Manufacture Composite Panel for Canal Blocking Module}

After coconut fiber has been determined as the main material for making composite canal block module, then the next step is to identify and determine the composition of materials that form the composite panel for canal block module and how the process is made. Composite materials are formed from a combination of two or more materials that have different mechanical properties through non-homogeneous mixing. Its mechanical properties and characteristics differ from the constituent material properties. So it will be easier to plan its strength by arranging the composition of the constituent material because composite is a combination of matrix material or fastener with amplifier (Matthews \& Rawlings, 1993). In general, composite materials consist of two elements, namely fiber, and binder called Matric. Composites can also be formed from a combination of two or more materials, either metal, organic or inorganic. Manufacturing of bio-waste material such as coconut fiber composite is included in the classification of randomly oriented discontinuous fiber (Schwartz, 1984). In the manufacturing of composites, three methods can be used, namely the Hand Lay-Up Method, Spray-Up Method, Vacuum Bag Method and Injection Mold Method. In this research, the method used for making composite canal bocking module is the Hand Lay-Up method, which is done by layer by layer method until the desired thickness is obtained, where each layer contains the matrix and filler, as shown in Fig. 3.

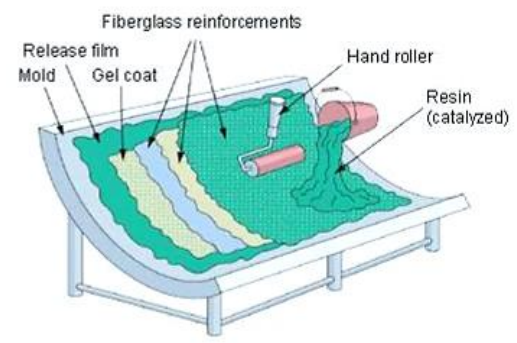

Fig. 3. Hand Lay-Up Methode (Source : http://wacker.com)

\section{STEP 4: Composite Panel Testing of Canal Block Module}

The next step is to test the composite panel for the canal block module based on SNI 01-4449-2006. Composite materials have several properties that are physical properties, the behavior of material properties that are not caused by the loading but rather lead to material structures such as density, water absorption, thickness swelling and lenght swelling.

Density is one of the physical properties of a composite board defined as the mass per unit of material volume, increasing regularly with increasing atomic numbers in each subgroup. Density depends on the atomic mass, size and way of its passenger. The magnitude of composite board density can be calculated using the following equation (Andriyansyah, 2014):

$$
\rho=\mathrm{m} / \mathrm{v}
$$

where $\rho$ is the composite board density $\left(\mathrm{gr} / \mathrm{cm}^{3}\right), \mathrm{m}$ is the composite board mass ( $\mathrm{gr}$ ), and $\mathrm{v}$ is the particle board volume $(\mathrm{p} \times 1 \times \mathrm{t})\left(\mathrm{cm}^{3}\right)$. Water Absorption is a percentage of water weight that is absorbed by the composite board in an equilibrium state with its surrounding environment. The amount of moisture content can be calculated using the following equation (Andriyansyah, 2014) :

$$
K A=\frac{m_{a}-m_{k}}{m_{k}} 100 \%
$$


where $\mathrm{KA}$ is the composite material moisture content $(\%), \mathrm{m}_{\mathrm{a}}$ and $\mathrm{m}_{\mathrm{k}}$ are the initial mass composite material and absolute mass dry composite material, respectively. Both are in gr.

Thickness swelling is a magnitude that represents a thick increase in test samples. To know the thickness swelling, the samples were soaked in water for 24 hours. Determination of the value of thick development can be calculated using the following equation, (Andriyansyah, 2014):

$$
P T=\frac{t_{2}-t_{1}}{t_{1}} 100 \%
$$

where PT is the thickness swelling of composite materials (\%), and $t_{1}$ and $t_{2}$ are thickness of material before marinated $(\mathrm{cm})$ and thickness of material after soaked $(\mathrm{cm})$, respectively.

Length swelling is a magnitude that expresses the length of a test sample. For that, samples were soaked in water for 24 hours. Determination of long change values can be calculated using the following equation (Andriyansyah, 2014):

$$
P T=\frac{P_{2}-P_{1}}{P_{1}} 100 \%
$$

where PT is the length development of composite material (\%), $\mathrm{P}_{1}$ and $\mathrm{P}_{2}$ are length of material before marinated $(\mathrm{cm})$ and length of material after soaked $(\mathrm{cm})$, respectively.

While mechanical properties are the behavior of material caused by loading such as modulus of elasticity (MoE), modulus of rupture (MoR), impact load and impact value. Modulus of elasticity is a value that demonstrates the nature of stiffness, is a measure of the ability of a material to withstand a change of shape or bending that occurs due to the liberation of the proportions. The modulus of elasticity is expressed as a comparison between stress and strain (Misrawati, 2015) where:

$$
E=\frac{\sigma}{\varepsilon}
$$

where $\mathrm{E}$ is the modulus of elasticity $\left(\left(\mathrm{N} / \mathrm{cm}^{2}\right), \sigma\right.$ is the stress $\left(\mathrm{N} / \mathrm{cm}^{2}\right)$, and $\varepsilon$ is the strain.

Forces that work on objects attempt to stretch objects so that modulus of elasticity can be calculated using the equation:

$$
\mathrm{MoE}=\frac{\Delta P L^{3}}{4 \Delta Y b d^{3}}
$$

where MoE is the modulus of elasticity $\left(\mathrm{kgf} / \mathrm{cm}^{2}\right), \Delta \mathrm{P}$ is the load difference $(\mathrm{kgf}), \mathrm{L}$ is the buffer distance $(\mathrm{cm}), \Delta \mathrm{Y}$ is the bending load $(\mathrm{cm}), \mathrm{b}$ is the test sample width $(\mathrm{cm}), \mathrm{d}$ is the test sample thickness $(\mathrm{cm})$.

Modulus of Rupture is the fracture strength of a material expressed in the magnitude of the tension per unit area, which can be calculated using the magnitude of the stress on the top surface and the bottom of the material at maximum load (Misrawati, 2015). The modulus of composite boards can be calculated using the following formula:

$$
M o R=\frac{3 P L}{2 b d^{2}}
$$

where MoR is the modulus of rupture $\left(\mathrm{kgf} / \mathrm{cm}^{2}\right), \mathrm{P}$ is the maximum load $(\mathrm{kgf})$.

Impact testing aims to measure how much energy a material can absorb to its breaking point. Impact testing is a response to shock or sudden loads. 


$$
\operatorname{Esrp}=m g R(\cos \beta-\cos \alpha)
$$

where Esrp is the energy absorbent $(\mathrm{J}), \mathrm{R}$ is the arm length $(\mathrm{m}), \mathrm{m}$ is the pendulum weight $(\mathrm{kg}), \mathrm{g}$ is the acceleration of gravity $\left(\mathrm{m} / \mathrm{s}^{2}\right), \alpha$ is the pendulum angle before swing, $\beta$ is the pendulum swing angle after breaking specimen.

Impact value can be calculated by

$$
\mathrm{Hi}=\operatorname{Esrp} / \text { Ao }
$$

where Hi is the impact value $\left(\mathrm{J} / \mathrm{mm}^{2}\right)$, and Ao is the specimen area $\left(\mathrm{mm}^{2}\right)$.

\section{STEP 5: Manufacture of Composite Canal Blocking Module Product}

Based on the result of the analysis and identification of the canal site that have carried out in the previous initial step, then the next step is to make a design for the canal blocking module. The design that has been produced will subsequently serve as the basis for manufacturing composite canal blocking module product. The composite canal module product designed and made is a type of plank dam for canal size with canal width 3 meters and canal depth 1 meters, according the result of the analysis and identification of canal that have been previously surveyed.

\section{STEP 6: Application of Composite Canal Blocking Module Product}

The composite canal blocking that has been made is then applied to the canal that has been analyzed and identified in the intial stages of this research activity, which is on the plantation area owned by PT. Muara Sungai Landak, in Mempawah Regency.

\section{STEP 7: Analysis and Discussion}

The final stage, the analysis and discussion is based on observations and tests on real conditions in the field of composite canal blocking module product that have been installed on the plantation area owned by PT. Muara Sungai Landak.

\section{RESULTS AND DISCUSSIONS}

\subsection{Physical and Mechanical Properties Analysis}

In this research, physical and mechanical properties analysis was performed on a composite panel of canal blocking modules. The composite panel is made up of 4 types, based on the composition type of the composite panel, as shown in Table 1.

Composite Panel Composition with thickness 15 mm.

Tabel 1.

\begin{tabular}{ccl}
\hline Panel ype & \multicolumn{1}{c}{ Matrix } & \multicolumn{1}{c}{ Layer Composition } \\
\hline A & Resin Polyester & $\begin{array}{l}\text { Mat Fiberglass - Mat Cocofiber - Wiremesh - Mat Cocofiber- Mat } \\
\text { Fiberglass }\end{array}$ \\
B & Resin Polyester & $\begin{array}{l}\text { Mat Fiberglass - Mat Cocofiber - Mat Fiberglass - Mat Cocofiber - Mat } \\
\text { Fiberglass } \\
\text { Mat Fiberglass - Wiremesh - Mat Cocofiber - Wiremesh - Mat Fiberglass } \\
\text { C }\end{array}$ \\
Resin Polyester & $\begin{array}{l}\text { Mat Cocofiber - Wiremesh - Mat Fiberglass } \\
\text { Mat Fiberglass - Wiremesh - Mat Cocofiber - Mat Fiberglass - Mat } \\
\text { Cocofiber - Wiremesh - Mat Fiberglass }\end{array}$ \\
\hline
\end{tabular}

The results of the physical properties (density, moisture content, thickness swelling, and length swelling) of the 4 types of canal blocking can be seen in Table 2 to Table 3 . 
Density Test and Moisture Content Result with Volume of $150 \mathrm{~cm}^{3}$

\begin{tabular}{ccccc}
\hline No & $\begin{array}{c}\text { Name of } \\
\text { Test } \\
\text { Sample }\end{array}$ & $\begin{array}{c}\text { Weight } \\
\text { (gr) }\end{array}$ & $\begin{array}{c}\text { Density } \\
\text { (gr/cm3) }\end{array}$ & $\begin{array}{c}\text { Average of } \\
\text { Density } \\
\text { (gr/cm3) }\end{array}$ \\
\hline 1 & A1 & 12,17 & 0,0811 & \\
2 & A2 & 11,94 & 0,0796 & 0,0808 \\
3 & A3 & 12,25 & 0,0817 & \\
4 & B1 & 12,38 & 0,0825 & \\
5 & B2 & 12,47 & 0,0831 & 0,0828 \\
6 & B3 & 12,41 & 0,0827 & \\
7 & C1 & 12,75 & 0,0850 & \\
8 & C2 & 12,83 & 0,0855 & $\mathbf{0 , 0 8 5 3}$ \\
9 & C3 & 12,81 & 0,0854 & \\
10 & D1 & 12,57 & 0,0838 & \\
11 & D2 & 12,62 & 0,0841 & 0,0838 \\
12 & D3 & 12,53 & 0,0835 & \\
\hline
\end{tabular}

\begin{tabular}{ccccc}
\hline No & $\begin{array}{c}\text { Name of } \\
\text { Test } \\
\text { Sample }\end{array}$ & $\begin{array}{c}\text { Initial } \\
\text { Weight } \\
\text { (gr) }\end{array}$ & $\begin{array}{c}\text { Final } \\
\text { Weight } \\
\text { (gr) }\end{array}$ & $\begin{array}{c}\text { Average } \\
\text { Moisture } \\
\text { Content } \\
(\%)\end{array}$ \\
\hline 1 & A1 & 12,17 & 12,21 & \\
2 & A2 & 11,94 & 11,98 & 0,33 \\
3 & A3 & 12,25 & 12,29 & \\
4 & B1 & 12,38 & 12,41 & \\
5 & B2 & 12,47 & 12,51 & 0,30 \\
6 & B3 & 12,41 & 12,45 & \\
7 & C1 & 12,75 & 12,77 & \\
8 & C2 & 12,83 & 12,85 & $\mathbf{0 , 1 6}$ \\
9 & C3 & 12,81 & 12,83 & \\
10 & D1 & 12,57 & 12,60 & \\
11 & D2 & 12,62 & 12,64 & 0,21 \\
12 & D3 & 12,53 & 12,56 & \\
\hline & & & & \\
\hline
\end{tabular}

Tabel 2.

Tabel 3.

Thickness and Length Swelling Result

\begin{tabular}{ccccc}
\hline No & $\begin{array}{c}\text { Name of } \\
\text { Test } \\
\text { Sample }\end{array}$ & $\begin{array}{c}\text { Thickness } \\
\text { Before } \\
\text { Soak } \\
(\mathbf{m m})\end{array}$ & $\begin{array}{c}\text { Thickness } \\
\text { After } \\
\text { Soak } \\
(\mathbf{m m})\end{array}$ & $\begin{array}{c}\text { Average of } \\
\text { Thickness } \\
\text { Swelling (\%) }\end{array}$ \\
\hline 1 & A1 & 15,14 & 15,17 & \\
2 & A2 & 15,12 & 15,16 & 0,29 \\
3 & A3 & 15,08 & 15,14 & \\
4 & B1 & 15,11 & 15,15 & \\
5 & B2 & 15,13 & 15,16 & 0,24 \\
6 & B3 & 15,14 & 15,18 & \\
7 & C1 & 15,09 & 15,11 & \\
8 & C2 & 15,12 & 15,14 & $\mathbf{0 , 1 1}$ \\
9 & C3 & 15,12 & 15,13 & \\
10 & D1 & 15,13 & 15,15 & \\
11 & D2 & 15,15 & 15,18 & 0,18 \\
12 & D3 & 15,11 & 15,14 & \\
\hline
\end{tabular}

\begin{tabular}{ccccc}
\hline No & $\begin{array}{c}\text { Name of } \\
\text { Test Sample }\end{array}$ & $\begin{array}{c}\text { Lenght } \\
\text { Before } \\
\text { Soak } \\
(\mathbf{m m})\end{array}$ & $\begin{array}{c}\text { Lenght } \\
\text { After } \\
\text { Soak } \\
(\mathbf{m m})\end{array}$ & $\begin{array}{c}\text { Average of } \\
\text { Lenght } \\
\text { Swelling } \\
(\mathbf{\%})\end{array}$ \\
\hline 1 & A1 & 200,08 & 200,15 & \\
2 & A2 & 200,11 & 200,15 & 0,03 \\
3 & A3 & 200,07 & 200,12 & \\
4 & B1 & 200,09 & 200,11 & \\
5 & B2 & 200,08 & 200,13 & 0,02 \\
6 & B3 & 200,12 & 200,16 & \\
7 & C1 & 200,09 & 200,10 & \\
8 & C2 & 200,10 & 200,12 & $\mathbf{0 , 0 1}$ \\
9 & C3 & 200,07 & 200,09 & \\
10 & D1 & 200,11 & 200,13 & \\
11 & D2 & 200,08 & 200,11 & 0,01 \\
12 & D3 & 200,10 & 200,14 & \\
\hline & & & & \\
\hline
\end{tabular}

Based on the test results of physical properties of 4 different types of coconut fiber canal block, the optimum results were obtained on type $\mathrm{C}$ composite panels, with a density value of $0.0853 \mathrm{gr} / \mathrm{cm}^{3}$, moisture content value $0.16 \%$, the thickness swelling value $0.11 \%$ and the length swelling value $0.01 \%$, and meet SNI 01-4449-2006 requirements for fiber board quality standards, particularly high-density fiberboard categories. Furthermore, the properties testing (MoE and MoR) for 4 types of canal block module, can be seen in Table 4 to Table 5.

Tabel 4.

Modulus of Rupture (MoR) with space of $200 \mathrm{~mm}$, thickness of $15 \mathrm{~mm}$ and area of $50 \mathrm{~mm}$

\begin{tabular}{ccccc}
\hline No & $\begin{array}{c}\text { Name of test } \\
\text { Sample }\end{array}$ & $\begin{array}{c}\text { Maximum } \\
\text { Force (kg) }\end{array}$ & $\begin{array}{c}\text { MoR } \\
\text { (kgf/mm2) }\end{array}$ & $\begin{array}{c}\text { Average of MoR } \\
\text { (kgf/mm2) }\end{array}$ \\
\hline 1 & A1 & 784,73 & 20,926 & \\
2 & A2 & 786,68 & 20,978 & 20,994 \\
3 & A3 & 790,36 & 21,076 & \\
4 & B1 & 798,74 & 21,300 & 21,387 \\
5 & B2 & 802,68 & 21,405 & \\
6 & B3 & 804,59 & 21,456 & \\
7 & C1 & 820,36 & 21,876 & \\
8 & C2 & 817,74 & 21,806 & \\
9 & C3 & 819,47 & 21,853 & \\
10 & D1 & 810,64 & 21,617 & \\
11 & D2 & 809,85 & 21,596 & \\
12 & D3 & 809,63 & 21,590 & \\
\hline
\end{tabular}


Tabel 5.

Modulus Elastisitas (MoE) with space of $200 \mathrm{~mm}$, thickness of $15 \mathrm{~mm}$ and length of $50 \mathrm{~mm}$

\begin{tabular}{cccccc}
\hline No & Sample name & Load Diff $(\mathbf{m m})$ & Def $\mathbf{~ m m})$ & MoE $\left(\mathbf{k g f} / \mathbf{m m}^{2}\right)$ & MoE $\left(\mathbf{k g f} / \mathbf{m m}^{2}\right)$ \\
\hline 1 & A1 & 284.73 & 50 & 67.492 & \\
2 & A2 & 288.62 & 50 & 68.414 & 67.974 \\
3 & A3 & 286.95 & 50 & 68.018 & \\
4 & B1 & 292.78 & 50 & 69.400 & \\
5 & B2 & 294.53 & 50 & 69.815 & 69.699 \\
6 & B3 & 294.82 & 50 & 69.883 & \\
7 & C1 & 329.62 & 50 & 78.132 & \multirow{2}{*}{$\mathbf{7 8 . 0 5 7}$} \\
8 & C2 & 331.46 & 50 & 78.568 & \\
9 & C3 & 326.83 & 50 & 77.471 & 73.606 \\
10 & D1 & 310.86 & 50 & 73.685 & \\
11 & D2 & 309.47 & 50 & 73.356 & \\
12 & D3 & 311.25 & 50 & 73.778 & \\
\hline
\end{tabular}

Further, the test results regarding the impact test on the 4 types of canal blocking, can be seen in Table 6 .

Table 6

$\underline{\text { Result of Impact Test with specimen area of } 196 \mathrm{~mm} \text { and pendulum weight of } 30.4 \mathrm{~mm}}$

\begin{tabular}{|c|c|c|c|c|}
\hline No & $\begin{array}{l}\text { Name of } \\
\text { test Sample }\end{array}$ & $\begin{array}{c}\text { Impact Energy } \\
\text { (joule) }\end{array}$ & $\begin{array}{c}\text { Average of Impact } \\
\text { energy (joule) }\end{array}$ & $\begin{array}{c}\text { Average Impact Value } \\
\left.\text { (joule } / \mathbf{m m}^{2}\right)\end{array}$ \\
\hline 1 & $\mathrm{~A} 1$ & 58.75 & & \\
\hline 2 & A2 & 59.27 & 58.99 & 0.301 \\
\hline 3 & A3 & 58.96 & & \\
\hline 4 & B1 & 66.87 & & \\
\hline 5 & B2 & 67.36 & 67.17 & 0.343 \\
\hline 6 & B3 & 67.28 & & \\
\hline 7 & $\mathrm{C} 1$ & 75.59 & & \\
\hline 8 & $\mathrm{C} 2$ & 79.74 & 79.66 & 0.406 \\
\hline 9 & $\mathrm{C} 3$ & 79.66 & & \\
\hline 10 & D1 & 66.77 & & \\
\hline 11 & D2 & 66.83 & 66.82 & 0.341 \\
\hline 12 & D3 & 66.85 & & \\
\hline
\end{tabular}

Based on the impact test of 4 types of canal blocking is made from coconut fiber, obtained the optimum value in the composite panel of type $C$, with impact energy value 79.66 joule and impact price of 0.406 joule $/ \mathrm{mm}^{2}$. Based on all test results on physical properties and mechanical properties in 4 types of composite panel samples, it obtained one of the most optimal type C. Composition for type C composite panel can be seen as in Fig. 4.
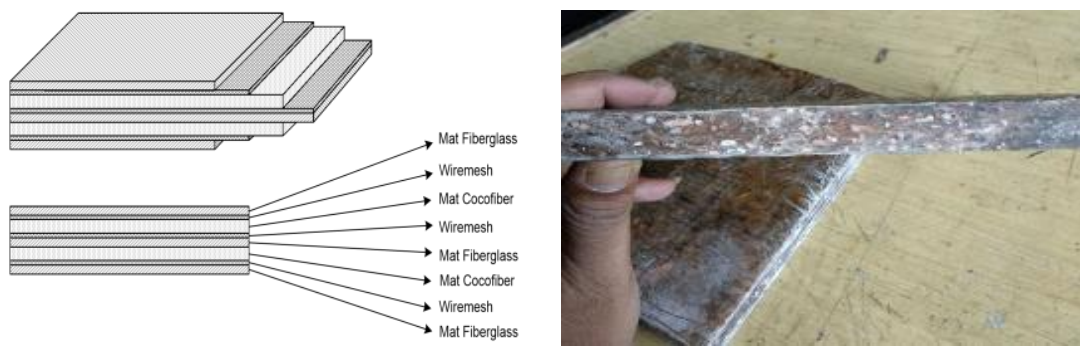

Fig. 4. Type C Composite Panel 


\subsection{Product of Composite Canal Block Module}

Based on the results of the analysis and identification of the canals that have been carried out in the previous survey stage, then the type of canal block module that will be made is the Plank Dam type for canals with a width of 3 meters and a depth of 1 meter. The product of composite canal block modules can be seen in Fig. 4.

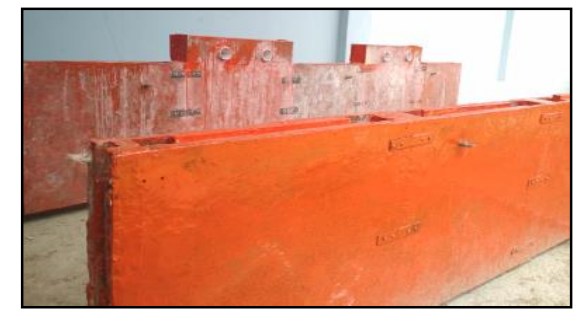

Fig. 4. Composite Canal Block Modules for Plank Dam Structure Type

\subsection{Application of Composite Canal Block Module Product}

In this research, a product of composite canal blocking module with a length of $400 \mathrm{~cm}$, a width of $150 \mathrm{~cm}$ and thickness $12 \mathrm{~cm}$ were applied in the test area on plantation area owned by PT. Muara Sungai Landak, as seen in Fig. 5. Based on the result of observation and evaluation, the time taken to install of composite canal block module structure only takes 7 days. The construction materials used also not too much, requiring only 15 bags of cement, $3 \mathrm{~m}^{3}$ sand, $1 \mathrm{~m}^{3}$ of stone size 5/7", and 8 PVC pipe rods $2.5^{\prime \prime}$ with the inside using reinforced concrete instead of wooden beams to strengthen the foundation pillars of the struktur composite canal block modules product.
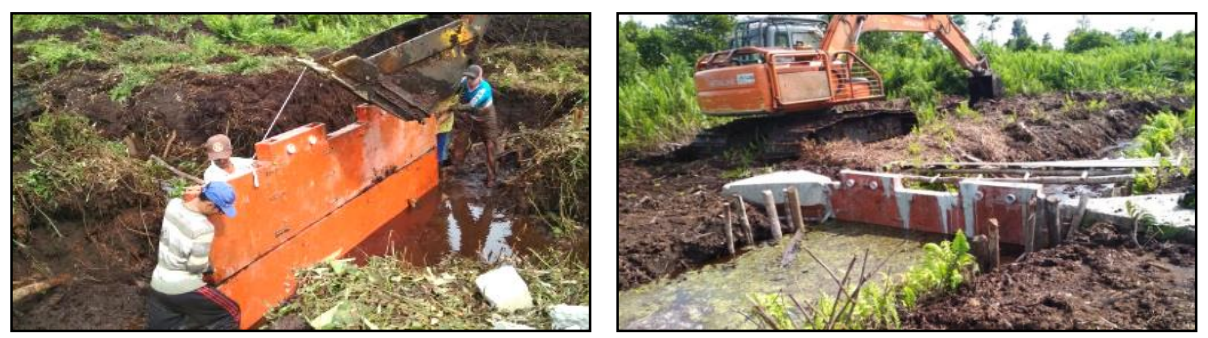

Fig. 5. Implementation Process of Composite Canal Blocking Module

\section{CONCLUSION}

Based on the results of density test, moisture content test, thickness swelling test and length swelling test on the 4 types of composite panel canal block module, obtained the most optimal result is type $\mathrm{C}$ composite panel, with a density value of $0.0853 \mathrm{gr} / \mathrm{cm}^{3}$, the value of moisture content by $0.16 \%$, thickness swelling value of $0.11 \%$ and 0.01 length swelling value, so sample type C composite panel met the SNI 01-4449-2006 standard about fibre board and entered in high density fibre board category. The sample type $\mathrm{C}$ composite panel also obtained the most optimal result, with MoR value of $21.845 \mathrm{kgf} / \mathrm{mm}^{2}$ and MoE value of $78.075 \mathrm{kgf} / \mathrm{mm}^{2}$. This shows a sample of type C composite panels above the minimum threshold for the category of high density fibre board type T1-20 based on SNI 01-44492006. Based on implementation of the composite canal blocking module product, indicated that the application process of composite canal block modules product is very effective and 
efficient, both in terms of time and materials usage for its construction. In addition, the composite canal block modules product also works optimally in controlling the flow rate of the surface run off on the aqueducts of the peatland. Wood-based material used for the frame of the composit canal blocking module should also be made from composite materials made from coconut-fiber waste, so that utilization of coconut-fiber waste as raw material for the composite canal blocking module products can be maximized.

\section{ACKNOWLEDGMENTS}

We present our sincere appreciation goes to Directorate Research, Development and Community Service of Research, Technology and Higher Education, Rector University of Tanjungpura, and Head of Untan's Research Community Service Institution.

\section{R E F E R E N C E S}

Andriyansyah, M. S. (2014). Physical Properties and Mechanical Properties of Particle Cement Mechanisms, Thesis, Universitas Negeri Semarang.

Artz, R. R. E, Johnson, S., Bruneau, P., Britton, A. J., Mitchell, R. J., Ross, L., Donaldson-Selby, G., Donnelly, D., Aitkenhead, M. J., Gimona, A., \& Poggio, L. (2019) The Potential for modelling peatland habitat condition in Scotland using long-term MODIS data International Journal of Environment, 660, 429-442

Dwianika, A., Murwaningsari, E., \& Suparta, W. (2020) Analysis of water awareness, accountability, governance to improve sustainability of firm's performance in urban areas. Geographia Technica, 15(1), 35-42.

Ighile, E. H. \& Shirakawa, H. (2020) A Study on the effect of land use change on flooding risk in Nigeria. Geographia Technica, 15 (1), 91-101.

Hayasaka, H., Yulianti, N. \& Usup, A. (2012) Recent Forest Fire Trends in Indonesia. Proceedings of International Symposium on Wild Fire and Carbon Management in Peat-Forest in Indonesia, 1126.

Matthews, F. L. \& Rawlings, R. D. (1993) Composite Material Engineering and Science, Imperial College of Science, Technology and Medicine, London, UK.

Miettinen, J., Hooijer, A., Shi, C., Tollenaar, D., Vernimmen, R., Liew, S. C., Malins, C. \& Page, S. E. (2012) Extent of industrial plantations on Southeast Asian peatlands in 2010 with analysis of historical expansion and future projections. Global Change Biology: Bioenergy 4, 908-918.

Ministry of Environment, (2012) Masterplan on Sustainable Peatland Ecosystem, West Kalimantan Province.

Misrawati, (2015) Physical and Mechanical Property of Particleboard from Sludge (Saccharum officinarum), Thesis, Universitas Islam Negeri Alauddin.

Najiyati, S., Muslihat, L. \& Suryadiputra, I. N. (2005) Guideline of Peatland Management for Sustainable Agriculture, Climate Change Project, Forest and Peatlands in Indonesia. Wetlands International Indonesia Programme and Wildlife Habitat Canada, Bogor - Indonesia.

Rafaai, N. H., Abdullah, S. A., Reza, M. I. H. (2020) Identifying and prediction the future land-use of protected area in the agriculture landscape of Malaysian peninsula for conservation planning International Journal of Remotes Sensing Application: Society and Environment, 18, 100298

Rotjanakusol, T. \& Laosuwan, T. (2019) An investigation of drought around chi watershed during tenyear period using terra/modis data. Geographia Technica, 14(2), 74-83

Satyanarayana, K. G., Pillai, C. K. S., Sukumaran, K., Pillai, S. G. K., Rohatgi, P. K., \& Vijayan, K. (1982) Structure property studies of fibers from various parts of the coconut tree. Journal of Material Science, 17, 2453-2462.

Wulffraat, A., Greenwood, C., Faisal, K. F. \& Sucipto, D. (2017). The environmental status of Borneo. Jakarta/Petaling Jaya, WWF Heart of Borneo Programme, 198 pp. 